\title{
Uplatnění pozdní filozofie L. Wittgensteina v myšlení C. Geertze
}

\author{
Kristina Vejnbender \\ Fakulta humanitních studií \\ Pátkova 2137/5, 18200 Praha 8 \\ Univerzita Karlova \\ kristina.veinbender@seznam.cz
}

Cílem článku je nabídnout analýzu toho, jakým způsobem uplatňuje Clifford Geertz pozdní filozofii L. Wittgensteina v metodologii společenských věd. Ve svých pracích Geertz vyjadřuje nesouhlas s brojením proti relativismu v antropologii, i když odmítá zaujmout pozici relativisty nebo anti-relativisty. Své pozici ř́ká anti anti-relativismus. Za hlavní problém obou táborů považuje mylnou představu kultury jako nedynamického a uzavřeného celku, která vyplývá z filozofické představy „ideálních“ pojmů. Taková představa je podle něj zvlášt neudržitelná v dnešním globalizovaném propojeném světě. Naopak, za vhodný metodologický nástroj považuje Wittgensteinovo pojetí „jazykové hry“, které nabízí pohled na jazyk a kulturu jako na sít vzájemně podobných praktik, které nejdou shrnout do základních premis a které netvoří celek s jasnými hranicemi.

Klíčová slova: anti anti-relativismus, antropologie, jazyková hra, Wittgenstein, Geertz

\section{Úvod}

Dějinám antropologie dlouhou dobu dominoval evropocentrický pohled na člověka a takzvané primitivní společnosti byly desítky let považovány za méně vyvinuté než ta západní. Zatímco evropské myšlení se postulovalo jako racionální, vědecké a logické, jiné kultury byly brány za evolučně nedospělé a iracionální. Praktiky nezápadních kultur byly v konečném důsledku prezentovány, jak formuloval Wittgenstein ve svých poznám- 
kách k Frazerovi z roku 1931, jako „hloupé“ nebo „chybné“. ${ }^{1}$ V době, kdy vyšla slavná kniha britského antropologa Richarda Evanse-Pritcharda Witchcraft, Oracles, and Magic among the Azande (1937)², v níž vědec popisuje magické rituály afrického kmene Azande, nebyl názor, že myšlení obyvatelů domorodých kmenů může postrádat racionalitu, logiku nebo zdravý rozum, vlastní pro lidi západní civilizace, vůbec výjimečný.

Ve své knize Evans-Pritchard popisuje místní pověry, podle kterých někteří lidé jsou čarodějové a dokážou ublížit jiným díky svým vrozeným a dědičným schopnostem. ${ }^{3}$ Přestože Evans-Pritchard odmítá evolucionistický pohled svých předchůdců (představený např́íklad J. Frazerem ve „Zlaté Ratolesti“), podle kterých se dají společnosti rozdělit na vyvinutější a méně vyvinuté, pořád na ně nahlíží normativní optikou západního antropologa. Podle jeho názoru by se sice dalo připustit, že vysvětlující roli vědy obsadila ve společnosti Azandů magie, nicméně podle něj chybí jejich uvažování vnitřní logická konzistence. $Z$ našeho pohledu se zdá, píše Evans-Pritchard, že pokud je prokázáno, že člověk je čaroděj, pak celý jeho klan tvoří ipso facto čarodějové, protože klan Zande je skupinou lidí, kteří jsou př́buzní přes mužskou linii. Azandové sice vidí logiku v tomto argumentu, nicméně odmítají přijmout jeho závěry. Pokud by to udělali, pak by celá představa o čarodějnictví byla kontradikční, uzavírá antropolog. ${ }^{4}$ Když Evans-Pritchard porovnává závěry Azandů a „náš pohled“, dochází k tomu, že jejich myšlení obsahuje silnou kontradikci, která znemožňuje racionální myšlení.

Racionalita a zdravý rozum jsou pro Evanse-Pritcharda univerzální (a teoretické) hodnoty, které se bud' manifestují v podobě, v jaké je definuje západní společnost, nebo zcela chybí. Oproti tomu relativistický pohled na kulturu považuje pojmy jako racionalita nebo zdravý rozum za zcela závislé na kontextu, v němž se objevují. Pojmy jako racionalita jsou pro relativisty praktikou, která je ukotvena hluboce v kultuře. Postupy, které aplikují př́slušníci kmene, jsou z pohledu relativistů stejně racionální jako ty západní, a to díky vlastnímu kontextu, v němž se vyskytují. Oba postoje, jak etnocentrismus, tak relativismus, se ve svých extrémních podobách vyznačují metodologickým problémem porozumění

\footnotetext{
1 Wittgenstein (1993b, s. 121).

2 Evans-Pritchard (1976).

3 Tamtéž, s. 1.

4 Tamtéž, s. 3.
} 
jiným kulturním kontextům. Zatímco etnocentrista považuje všechny příslušníky kmene Azande za neracionální, relativista není schopen rozpoznat ty racionální od těch neracionálních.

V tomto článku bych chtěla představit další cestu, která je inspirována pozdní filozofií Ludwiga Wittgensteina a která místo toho, aby zaujala jednu ze zmíněných pozic, zpochybňuje pohled na kulturu jako takový. Touto cestou se vydal antropolog Clifford Geertz a jeho anti anti-relativismus z velké části pramení z jeho interpretace Wittgensteinova pozdního díla.

Cílem článku je analyzovat zpo̊sob, jímž Geertz využil pozdní filozofii L. Wittgensteina, aby nejen odmítl myšlenku univerzality pojmů a významů např́íč kulturami, jak to dělali jiní zastánci Wittgensteina, ale i ukázal, jak taková debata vyhrocena do dvou protipólo̊ postrádá smysl. Stejně jako Wittgenstein se domníval, že kulturní významy se produkují na základě každodenních praktik v rámci sociálního a jazykového kontextu, v nichž se nacházejí. Z Wittgensteina si ovšem odnesl mnohem víc než kulturní podmíněnost pojmů. Inspiroval se Wittgensteinovou koncepcí různorodosti jazykových her a domníval se, že kultura, stejně jako jazyk, je souborem rozmanitých praktik, které se nedají shrnout pomocí několika premis. Stejně jako Wittgenstein zpochybnil představu pojmů jako jasně vymezených množin. Když to aplikoval na pojem kultury, došel k závěru, že není možné zkoumat kulturu či společnost jako uzavřený a statický celek. Konfrontace s cizím a odlišným je podle něj nepostradatelná pro utváření pocitu vlastní identity. Dochází tak podle něj k dialektickému vztahu, kde vlastní identita ovlivňuje porozumění cizímu, které v druhé řadě utvář́i identitu.

V první části článku popíšu kontext tzv. debaty o racionalitě, kde představím dva základní názorové tábory účastníků debaty - relativistů a anti-relativistů, zastoupené P. Winchem a E. Gellnerem. Geertz se díky vlivu Wittgensteinových myšlenek, které také krátce shrnu, odmítl hlásit k některému z těchto z postojů. Zaujal pozici anti anti-relativisty a inspirovaný Wittgensteinem pracoval s představou kultury jako celku složeného z mnoha (jazykových) her. Třetí a závěrečná čtvrtá část se budou věnovat tomu, jak Geertz aplikoval konkrétní rysy jazykové hry na pojem kultury. Skrze rozbor jeho přístupu se na závěr dotkneme i otázky relevantnosti jeho metodologických poznámek vůči současné antropologii. 


\section{Je racionalita kulturně podmíněna?}

Přestože v době vydání výzkumu Azande pořád společnosti dominoval etnocentrimus, s odstupem let se našli tací, kteří závěry Evanse-Pritcharda ostře kritizovali. Tato kritika se do společenskovědních dějin zapsala jako „debata o racionalitě“, časem se přestala zabývat jen konkrétními závěry ohledně myšlení Azande a přerostla do podoby obecné otázky, zda racionalita nebo jakákoliv jiná lidská vlastnost je kulturně podmíněná či nikoliv. $\mathrm{V}$ této části shrneme dva protipóly debaty. Jeden z nich, kulturní relativismus inspirovaný Wittgensteinem představoval P. Winch, jeho hlavním odpůrcem, stejně jako odpůrcem celé filozofie Wittgensteina byl E. Gellner. Na konci kapitoly naznačíme, kterou z cest se rozhodl vydat samotný Geertz.

Etnocentrické závěry Evanse-Pritcharda poprvé veřejně konfrontoval Wittgensteinem ovlivněný filozof Peter Winch, který ve svém článku „Understanding a primitive society“ vznesl námitku, že různé kultury mají různá kritéria pro to, co se dá považovat za racionální. ${ }^{5}$ Podle Winche nám samotný jazyk a společnost, v níž žijeme, ukládá to, co později považujeme za smysluplné nebo racionální a co ne, nikoliv naopak. „Schopnost vidět tento druh smyslu v životě nezáleží pouze na jedinci, kterého se to týká, i když se nedá říct, že na něm to nezáleží vưbec; také to záleží na podmínkách smysluplnosti, které poskytuje nebo neposkytuje společnost, v níž žije, " píše. ${ }^{6}$

Stejnou myšlenku vyjádřil už dřív ve své knize Idea sociální vědy a její vztah $k$ filosofii (1984), ${ }^{7}$ kde poukázal na to, že pokud chceme porozumět zkoumané společnosti, je potřeba se řídit jejími pravidly utváření významů:

„Koncepty a kritéria, podle nichž sociolog usoudí, že ve dvou situacích došlo $k$ témuž, př́padně že byla prováděna táž činnost, je třeba chápat ve vztahu k pravidlům řídícím sociální bádání. Zde však narážíme na vážnou potíž, nebot' v př́ípadě př́rodovědce se musíme vypořádat jen $\mathrm{s}$ jedním souborem pravidel, totiž s tím, jenž rídí vědecké bádání samo, zatímco $\mathrm{v}$ př́padě sociologa je lidskou činností nejen vlastní studium,

5 Winch (1970).

6 Tamtéž, s. 106.

7 Winch (2004). 
nýbrž i to, co studuje. Odtud plyne, že to, co sociolog studuje, musí být vykonáváno podle pravidel, ovšem právě tato pravidla - spíše než ta, jimiž se řídí sociologické bádání - určují, co se ve vztahu k danému typu činnosti pokládá za ,dělání téhož “"8

Myšlenka kulturního relativismu rozhodně nevznikla během takzvaných debat o racionalitě, které částečně rozpoutal Winch. Za sociologického předchůdce kulturních relativistů je často považován Max Weber a jeho teorie funkcionalismu. Ostatně kritik kulturního relativismu, Ernst Gellner, mluví o Winchově (a Wittgensteinově) přístupu výlučně jako o „extrémní podobě funkcionalismu“. 9 Relativistický postoj, který se zformoval během debaty o racionalitě, nejde ovšem zcela ztotožnit s funkcionalismem. Jak podotýká Bryan R. Wilson v úvodu ke sborníku Rationality, přestože ze všech klasických sociologů se Weber se svým funkcionalismem dostal nejblíž k „uznání hranic racionálních postupů výzkumů a porozumění“, nikdy nezpochybnil kritéria racionality samotné. ${ }^{10}$ „Funkcionalismus byl přístupem, který ospravedlňoval výzkum neracionálního chování tím, že odkazoval na ne tolik iracionální „skrytou ruku“, díky níž fungování bylo založeno na vzájemném doplňování se,“ pokračuje Wilson. ${ }^{11}$ Za výdobytek debaty o racionalitě, kterou zahájil P. Winch, můžeme podle Wilsona považovat zpochybnění kritérií racionality jako takových.

Podle Winche, samotná „forma koncepce reality předchází tomu, že rozumíme výrazu ,co věda označuje za pravdivé““. ${ }^{12}$ Nejen vědecká metodologie, ale i řízení se pravidly metodologie vyžadují určitý způsob před-porozumění tomu, co znamená řídit se pravidlem. Právě způsob, jímž přemýšlíme o věcech, určuje, co považujeme za vědecky pravdivé a co nikoliv. Věci, které zpochybňujeme, a tedy zkoumáme, si vybíráme na základě toho, co považujeme za nezpochybnitelnou pravdu a co za úsudek, názor, který jde vyvrátit. Např́lklad, praktiky, které Azande praktikují v souladu s tím, čemu západní civilizace ř́́ká racionalita, ignorujeme jako samozřejmé. Naopak, ty, co jsou v rozporu s naší představou o tom,

8 Tamtéž, s. 88.

9 Gellner (1970, s. 21), Wilson (1970).

10 Wilson (1970, s. vii).

11 Tamtéž.

12 Winch (2004, s. 94). 
co znamená chovat se racionálně, zkoumáme pod drobnohledem. Z pohledu kulturního relativisty máme ke všem praktikám přistupovat jako ke smysluplným, jelikož samotná existence praktiky v rámci kulturní formy je do̊kazem její smysluplnosti.

Hlavní kritik tohoto epistemologického relativismu, E. Gellner, napsal výsměšně: „Ve filozofii a v současném širším intelektuálním klimatu existují výrazné síly, které podporují druh funkcionalismu, kterému dává smysl všechno." ${ }^{13}$ Gellnerova hlavní výtka vůči postoji, který zastává Winch, skutečně spočívá v tom, že „funkcionalismu dává smysl všechno“. Způsobila to podle něj jedna skutečnost, a to že se díky Wittgensteinově pozdní filozofii „jazyk náhle stal svým pánem“. ${ }^{14}$ Už nepotřeboval externí legitimizaci, jelikož normy a praktiky, které se objevují v rámci jazyka, se staly legitimizující samy o sobě. ${ }^{15}$ Sociální praktika měla právo na existenci a považovala se za smysluplnou jenom díky tomu, že byla zaznamenána v řeči. Odpověd’ na otázku, proč používáme jazyk tak či onak, se najednou stala jednoduchá - protože to děláme.

Pokud validita jazyka spočívá v jeho vlastním užití, potom každá praktika, at’ už náboženská nebo kulturní, má právo na existenci, vytýkal Wittgensteinovým následovníkům Gellner. Filozofie by ji podle tohoto pohledu potom měla „ponechat takovou, jaká je“, tedy popsat bez možnosti kritizovat nebo porovnat s jinými praktikami. „Pokud užití je zároveň významem, potom, zcela jistě, náboženská tvrzení mají smysl, copak nejsou užívána, nemají své užití a funkci,“ soudí. ${ }^{16}$ Podobný metodologický přístup zajištuje validitu všem náboženským a ideologickým směrům, aniž by bylo možné některé z nich označit za nesmyslné nebo je vzájemně porovnávat.

Geertzův př́íspěvek k debatě, článek „Distinguished Lecture: Anti Anti-Relativism“17, vyšel teprve v době, kdy se debata už nedala považovat za aktuální. Jeho pozdní zapojení se do diskuze ovšem není chybou právě díky tomu nemusel uspěchaně zaujmout jeden z radikálních názorů a mohl si dovolit kriticky zhodnotit postoje každé strany.

\footnotetext{
13 Gellner (1970, s. 46).

14 Gellner (2005, s. 13).

15 Tamtéž.

16 Tamtéž, s. 291.

17 Geertz (1984).
} 
Kulturní relativismus zastávaný Winchem se skutečně vyznačoval několika teoretickými problémy, které úspěšně zneužívali jeho odpůrci jako Gellner. Odpor vưči relativismu spočíval ve „strachu, že nám kvůli důrazu na rozmanitost, diverzitu, odlišnost, diskontinuitu, vzájemnou nesouměřitelnost, unikátnost ... nezbude nic víc než konstatovat, že se věci jinde mají jinak a kultura činí to, co činí“. ${ }^{18}$

Obava z toho, že relativismus znemožní existenci antropologie, byla ovšem podle Geertze trochu přehnaná. Jak se píše v úvodu ke sborníku Rationality and Relativity, který představoval druhé kolo debat kolem racionality, relativismus „byl v sociální antropologii př́itomen vždy, i když se mu částečně, ale pevně bránilo“. ${ }^{19}$ Podle názoru Geertze dlouhodobé brojení proti relativismu připravovalo antropology o důležitý nástroj zkoumání, který byl spjat se samotnou podstatou antropologického zkoumání:

„At’ už kulturní relativismus původně byl nebo je čímkoliv (a není jediný kritik ze sta, který by ho pochopil správně), dnes slouží z velké části jako strašidlo, které nás má odpudit od určitých zpo̊sobů přemýšlení a přilákat $\mathrm{k}$ jiným. A jelikož ty způsoby myšlení, od nichž jsme odpuzováni, se zdají být přesvědčivější než ty, ke kterým jsme poháněni, a také se zdá, že se ony způsoby nacházejí v srdci antropologického dědictví, chtěl bych s tím něco udělat. Zahánění démonů je praxe, kterou bychom měli provozovat do stejné míry jako samotný výzkum. “20

Nezamlouvaly se mu ani posměšné a povrchní útoky na relativismus. Zatím co etnocentrismus se odmítl zabývat čímkoliv kromě vlastních hodnot, relativismus byl často prezentován jako „nihilismus“.21 Zastánci relativismu byli najednou obviňováni z toho, že „nevěří v existenci fyzikálního světa“ nebo „považují Hitlera jen za chlapíka s neobvyklými zálibami“.22

18 Tamtéž, s. 267.

19 Hollis (1982, s. 1).

20 Geertz (2000a, s. 43).

21 Geertz (1984, s. 264).

22 Tamtéž. 
Geertz se nicméně odmítl hlásit jak k relativismu, tak k anti-relativismu, protože debata, která by měla být analytická, mu často připomínala „výměnu vzájemných varování“. ${ }^{23}$ Anti-relativisté nám nabízejí „znepokojení, vyvolané př́lišným uvažováním o anthropu obecně, že pokud něco není ukotvené všude, pak nemůže být ukotvené nikde“. ${ }^{24}$ Relativismus nás naopak varuje před „provincialismem - nebezpečím, že naše vnímání se otupí, rozum se omezí, a naše schopnost porozumění se zúží díky příliš vědeckému a př́iliš vítanému přijetí vlastní společnosti“. ${ }^{25}$

Debata mezi dvěma tábory by se dala výstižně shrnout Jacksonovým popisem propasti mezi etnografickým a filozofickým přístupem: etnografie vyžaduje absolutní ponoření do světa jinakosti a jiných, zatímco filozofie nás chrání před utonutím tím, že nám poskytuje pocit srozumitelnosti, vyrovnanosti a kontroly v matoucím a nepřehledném světě. ${ }^{26}$ Černobílá volba mezi pohledem božího oka filozofa (Gellnera) a etnografickým pohledem domorodce (Winche) Geertzovi nevyhovovala. Představovaly pro něj dvě strany jedné mince - neumožňovaly výzkumníkovi zkoumat a porozumět praktikám, které by byly odlišné od jeho vlastních, aniž by se musel vzdát vlastního pohledu na svět.

Geertz hledal cestu, která by nebyla tolik extrémní a pracovala jak s výchozí identitou výzkumníka, tak svébytností předmětů zkoumání, a Wittgensteinova filozofie mu takovou cestu poskytla. „Pokud je pravdou to, že jsme připraveni nazvat našimi učiteli ty spisovatele, kteří podle našeho zdání konečně vyslovili to, co jsme sami měli dlouho na jazyku, ale nebyli schopní to vyjádřit ... pak můžu s potěšením nazvat Wittgensteina svým mistrem, " napsal. ${ }^{27}$ Nastiňme si, jaké Wittgensteinovy myšlenky tu měl Geertz na mysli.

Zřejmě nejzásadnější vliv na Geertzovo myšlení měla Wittgensteinova představa jazyka jako souboru jazykových her. Je základem toho, k čemu Geertz odkazuje jako k „návratu praktické filozofie““.28 Krátce si tuto představu zreprodukujme. Svůj význam získávají podle (pozdního) Wittgensteina slova a věty díky kontextu, v němž se nacházejí, - díky

23 Geertz (2000a, s. 46).

24 Tamtéž.

25 Tamtéž.

26 Jackson (2014, s. 28).

27 Geertz (2000a, s. xi).

28 Tamtéž, s. 139. 
užšímu kontextu v sociální i jazykové praxi v okamžiku mluvení, tedy v jazykové hře, a širšímu kontextu praktik, které se provozují v kultuře nebo společnosti, tedy životné formě. „... promlouvání řeči je částí určité činnosti nebo určité životní formy, " píše. ${ }^{29}$ Wittgensteinova pozdní filozofie decentralizuje pohled na význam jako na pevnou a univerzální danost a poukazuje na různé způsoby užití stejných slov a vět v různých situacích a celcích. Z takového pohledu plyne, že např́iklad představa o racionalitě nebo zdravém rozumu souvisí s kontextem kulturních a jazykových praktik.

Pojmy nenabývají smyslu v teoretickém kontextu věty, jsou součástí činnosti. Jazyk je pro Wittgensteina sociální praktikou, proto představa o tom, co je například zdravý rozum, se odvíjí od toho, co děláme, jak jednáme a co říkáme v běžném životě. Životní forma pak představuje sdílenou praxi a společná přesvědčení, o kterých za běžných okolností nepochybujeme a které aktivně uplatňujeme v řeči, aniž bychom se o tom zamýšleli. „Správné a chybné je to, co lidé říkají, a v řeči se lidé shodují,“ míní Wittgenstein. ${ }^{30}$ Neshodneme-li se v jednotlivých míněních, diskutujeme o tom a snažíme se přesvědčit se navzájem. V řeči, tedy životní formě se ale shodujeme, aniž bychom o tom museli diskutovat. Když mluvíme, řídíme se pravidlem, sdělujeme, dáváme rozkazy, nezpochybňujeme své jednání ze své podstaty. Když ř́íkáme, že něco takto děláme odjakživa, znamená to, že se řídíme návyky nebo zvyklostmi. ${ }^{31}$ Jinými slovy, pohled na svět je sociálně reprodukovatelná činnost, která se předává z generace na generaci a která nejde hodnotit z hlediska kritérií smysluplnosti nebo nesmyslnosti.

„Ř́lká se, že ,každý pohled má své kouzlo‘, ale není to pravda. Správné je říct, že každý pohled má svůj význam pro toho, kdo v něm ten význam vidí (což ale neznamená, že ho vidí jinak, než jaký je). Vskutku, v tomto smyslu je každý pohled stejně významný, " vysvětluje své stanovisko filozof. ${ }^{32}$ Praxe je tedy smysluplná vždy, jelikož aktér vykonávající praktiku vkládá smysl do svého jednání, případně smysl je neoddělitelnou součástí jednání. Z toho plyne, že pro porozumění praxi nestačí podat pouhý souhrn aktivity, ale i kontext, z nějž vzniká smysluplnost aktivity. Klíč

29 Wittgenstein (1993a, § 23).

30 Tamtéž, § 242.

31 Tamtéž, § 199.

32 Wittgenstein (1993b, s. 135). 
k pochopení tohoto kontextu se nachází v detailech každodennosti, a to nejen podle Wittgensteina, ale i Geertze.

Ve své poslední knize Available Light se antropolog explicitně hlásí k filozofům „běžného“, kteří „věří, že odpovědi na nejobecnější otázky jako ,Proč? Jak? Co? Kam?‘ se dají najít v drobných detailech žitého života do té míry, do které odpovědi na ně vůbec existuji“".33 Právě detaily každodennosti podle něj dokážou poskytnout odpovědi na otázku, ,jak skupiny lidí, lidé jako jednotlivci a lidé jako celek, míchají své rozmanité a pestrobarevné hlasy dohromady“. ${ }^{34}$ Jak si později ukážeme, tímto Geertz odmítá pátrat po iluzorní „hloubce“, tedy obecných závěrech, a postuluje, že v práci antropologa - použijme slova Wittgensteinova „jakékoliv vysvětlování musí odpadnout, a na jeho místo musí nastoupit jedině popis“. ${ }^{35}$ Pohledu na kulturu jako praxi a nutnosti se zabývat jejím popisem se budeme věnovat $\mathrm{v}$ dalčí části textu.

\section{Návrat na drsnou půdu: kultura jako praxe}

Geertzův pohled na kulturu jako na praktickou činnost jde nejlépe předvést na př́kladu jeho úvahy o zdravém rozumu.

V knize Local Knowledge se antropolog ostře vymezil vůči analytické tradici, která podle něj považuje „zdravý rozum“ za univerzální způsob lidského uvažování, k němuž často apeluje jako k univerzální samozřejmosti. Místo toho definoval zdravý rozum jako kulturní formu, pro kterou je sice vlastní „přirozenost“, „praktičnost“, „,nemetodičnost“ a „bezprostřednost“", to všechno ale podle něj souvisí s širším kontextem kulturního pozadí. ${ }^{36}$

Zdravý rozum je tedy podle něj kulturně podmíněný. Na jednu stranu, stejně jako oxfordští filozofové jazyka přistupuje ke zdravému rozumu jako k něčemu bezprostřednímu, obsaženému v samotné „situaci, vnitřních aspektech reality, ve způsobu, jak se věci mají“. ${ }^{37}$ Na rozdíl od nich ale považuje zdravý rozum za mnohem „problematičtější a zásadnější záležitost, než se to zdá z pohledu Pař́̌žské kavárny nebo Ox-

33 Geertz (2000a, s. xi).

34 Tamtéž, s. xii.

35 Wittgenstein (1993a, §109).

36 Geertz (1993, s. 85).

37 Tamtéž. 
fordské sborovny“ ${ }^{8}{ }^{8}$ Odmítá akceptovat naturalistické vidění, v němž je zdravý rozum postaven na objektivně daných přírodních faktech, a má tedy univerzální charakter. Naopak, pohled na to, jak se věci mají, podle něj souvisí do velké míry s kulturním pozadím jedince. Pro „primitivní“ národy není svět plný duchů zviřrat o nic méně přirozený, běžný nebo bezprostř̌ední než ten náš, argumentuje. Logika magie je tedy projevem zdravého rozumu do stejné míry, do jaké je uvažování obyvatel Západu. Tento závěr by se u kulturního relativisty dal snadno očekávat. Ale Geertz jde dál a poukazuje na další důležitou vlastnost zdravého rozumu, konkrétně na to, že má podobu jednání.

Když začíná pršet, schováme se pod střechou, protože jinak zmokneme. Ani nestrkáme ruce do ohně, protože se můžeme popálit. „Nikdo při smyslech nepochybuje o tom, že déšt je mokrý; ale najdou se takoví, kteří zpochybní propozici ohledně potřeby se schovat dovnitř, když prší, např́iklad, že je to dobré pro posílení vưle..." 39 Nepochybujeme tedy o tom, co je rozumné nebo přirozené udělat $\mathrm{v}$ té či oné situaci, ale o tom, co by nám mohl přinést opak. Naopak, když o někom řekneme, že jeho chování postrádá zdravý rozum, nemíníme tím, že je „mentálně zaostalý a že nedokáže pochopit, že během deště je mokro a oheň pálí, ale že nedokáže čelit každodenním problémům, které se v životě vyskytují...,“ píše Geertz. ${ }^{40}$

Z Geertzova pohledu nejsou představitelé kmenu Azande o nic hloupější nebo schopnější v řešení běžných problémů než obyvatelé Západu. Jednoduchým vysvětlením jejich odlišného uvažování je jiný způsob jednání, na který jsou zvyklí. Zdravý rozum je pro Geertze především naučené, sociálně reprodukované, kulturně podmíněné každodenní jednání a také postoje, obojí založené na interakci se světem. V tomto zrcadlí Geertz Wittgensteinovu představu životní formy, kterou shrnuje takto: Jednám tak. ${ }^{41}$

Další položkou k zamyšlení je fakt, že některé praktiky mohou být zcela $\mathrm{v}$ rozporu s teoretickými názory, které zastáváme. Když Evans-Pritchard poukazuje na nelogičnost myšlenkových postupů Azandů během procesů identifikace čarodějů, dochází k závěru, že Azandové

\footnotetext{
38 Tamtéž, s. 77.

39 Tamtéž, s. 75.

40 Tamtéž, s. 76.

41 Wittgenstein (2010, § 148).
} 
postrádají logické uvažování. Azandové přesto uznávají jeho teoretické argumenty jako platné, ty pro ně ale nesouvisí s praktickou, každodenní stránkou věcí, tedy s tím, co považují za zdravý rozum. Stejný „paradox“ popisuje Cora Diamond v článku „Rules: looking in the right place“:42

„Pokud těmto lidem sdělíte, že ,medvědi na dalekém severu, kde sněží, jsou bílí, a Nová země se nachází na dalekém severu, kde je sníh‘ a pak se jich zeptáte ,Jakou barvu mají tamější medvědi?‘, odpoví, že vám to nejsou schopní říct, jelikož tam nikdy nebyli. Přitom jsou to lidé, kteří jsou bezpochyby schopni odvodit závěry o věcech, které mají v okolí a s nimiž přicházejí do styku. Nicméně jejich odpovědi výzkumníkům se dají označit za ,gramatické připomínky': ,Vždycky mluvíme o tom, co jsme viděli, a nikdy o tom, co jsme nikdy neviděli"“..43

Stejně jako v případě Azandů lidé z výše popsaného kmene disponují schopností logického odvozování, nicméně jejich běžné praktiky nejsou vždy založeny na tomto principu. Zdá se, že každodenní praxe nemusí mít normativně-racionální základ, nicméně znalost a zběhlost v těchto praktikách je pokládána za základ zdravého rozumu. „Když říkáme, že někdo má zdravý rozum, také předpokládáme, že ... je schopen si s problémy poradit běžným způsobem a zároveň účinně. “44 Zdravý rozum jako kulturní forma není podle Geertze ukotven v teorii, ale v praxi. Je souhrnem rozlišných praktik, které si mohou vzájemně protiřečit. V tomto smyslu hra na „racionální“ myšlení je jen jednou z praktik, které v rámci kultury provozujeme. Stejně jako Diamond se Geertz domnívá, že praxe nemůže být posuzována teoretickým zobecňujícím měřítkem či pravidlem. Při pokusu o zobecnění bychom tímto přišli o spoustu případů, které se vymykají jak naší zkušenosti, tak obecné formulaci. Tento závěr má především významný dopad na představu o antropologii jako vědě.

Etnografovi podle Geertze totiž nezbývá nic jiného než sbírat „letmé př́iklady utvářeného chování“. ${ }^{45} \mathrm{O}$ to se pokouší už ve svém raném díle

\footnotetext{
42 Diamond (1989).

43 Tamtéž, s. 24-25.

44 Geertz (1993, s. 76).

45 Geertz (200ob, s. 20).
} 
Interpretace kultur z roku 1973, kde pro metodologii sběru dat využívá termín „thick description“ (zhuštěný popis), který přebírá od G. Ryle a navazuje na Wittgensteinovu myšlenku významu jako užití. ${ }^{46} \mathrm{Jde}$ o takový popis, který čtenáři nebo divákovi poskytne nejen deskripci lidského chování, ale přiblíží i praxi, v rámci které dává smysl. Místo toho, aby analýza kultury vypadala jako „hrdinský ,holistický útok na ,základní konfigurace kultury“, překlenující ,řád řádů‘, ze kterého mohou být skromnější konfigurace nahlíženy jako pouhé dedukce," věnuje se popisu běžné řeči a každodenních praktik. ${ }^{47}$

Jeden z příkladů uplatnění tohoto pohledu najdeme už v jeho raném díle, v Interpretaci kultur. Když se dá do zkoumání kultury Balijců, zjistí, že hledání „Balijské povahy“ byl věnován nespočet studií, kde byly prozkoumány „mytologie, rituály, společenská organizace, vzorce výchovy dětí, formy práva, dokonce i styly transu“. ${ }^{48}$ Překvapující je pro něho ovšem to, že jen málo literatury se věnuje praxi kohoutích zápasů, i když „každý, kdo byl nějakou dobu na Bali, neomylně poznal hlubokou psychologickou identifikaci balijských mužů s jejich kohouty. ${ }^{49}$ Ukazuje, že běžné praktiky Balijců často odkazují ke kohoutí symbolice, například že běžná řeč je plná odkazo̊ ke kohoutům ve vztahu k mužům. ${ }^{50}$ Skrze podrobný detailní popis zápasů se tak Geertz dostává mnohem „hlouběji“ do kultury než ti, co pátrají po obecné hloubce od samého začátku.

Máme-li shrnout myslitelův programový postoj, pak můžeme říci: Geertz je přesvědčen, že jedině skrze popis praxe se dostaneme k porozumění různým aspektům kultury. Navíc, nejde o praxi jednoho typu, ale velice rozmanitý přehled praktik. Rozmanitosti kultury se budeme věnovat v další části.

\section{Z vlaku na nádraží}

V minulé části jsme naznačili, že se Geertz neomezuje pouze myšlenkou kulturně podmíněného významu. Jeho postoj je značně ovlivněn Wittgensteinovým pojetím jazykové hry, která má povahu činnosti, a proto

46 Tamtéž, s. 6.

47 Tamtéž, s. 451.

48 Tamtéž, s. 460.

49 Tamtéž.

50 Tamtéž, s. 465. 
není redukovatelná na premisy a shrnující závěry. Jelikož jednání není ukotveno v žádném základu než v sobě samém, je těžké shrnout tento základ pomocí obecných vět. A jednotlivé praktiky mohou dokonce být v rozporu s teoretickými domněnkami, pravidly či logikou uvažování. Je tedy problematické posoudit kulturní činnost jako logicky konzistentní nebo nekonzistentní, tedy racionální či neracionální, protože nejde o souhrn vět, ale soubor různorodých praktik.

Druhým rysem jazyka, a podle Geertze i kultury, je jeho vysoká vnitřní heterogennost. Dopadu tohoto pohledu na představu kultury se budeme věnovat v této závěrečné části. Podobně jako je jazyk tvořen nespočtem rozličných (jazykových) her, kterými se prolíná sít rodinných podobností, stejně tak je kultura tvořena nespočtem rozličných praktik, které se navzájem prolínají a kř́íží. A to „podobnosti ve velkém i v malém,“ upřesňuje Wittgenstein. ${ }^{51}$ Zároveň naše touha po tom, abychom ponechali jenom ty „velké“ podobnosti a pevné hranice, může být zaslepující, a to jak v pohledu na jazyk, tak na kulturu.

Právě taková zaslepenost, která pramení z nepochopení vnitřní rozmanitosti pojmů, dominuje podle Geertze tradiční představě o kultuře. Ostatně, jako hlavní a přetrvávající problém sociálních a humanitních věd vidí antropolog „tendenci vnímat diverzitu jako povrch, ale univerzalitu jako hloubku“. ${ }^{2}$ Geertzova kritika navazuje na tu Wittgensteinovu, kterou vyjadřuje ve Filozofických zkoumáních: „Problémy, které vznikají špatným chápáním našich řečových forem, mají charakter něčeho hlubokého,“ konstatuje.53 Jelikož jsme zaslepeni ideálem logické „hloubky“ jako dobré odpovědi, všude hledáme univerzalitu, obecnost a pravidelnost. Jenže abychom pochopili kulturu, nestačí (ani to není možné) jednoduše katalogizovat obsah kulturní formy, domnívá se. Její obsah je podle antropologa tak „vysoce heterogenní, a to nejen napříč společnostmi, ale i uvnitř jednotlivých společností, že žádná logická struktura v nich nejde identifikovat, protože tam jednoduše není“. ${ }^{54}$ Existuje jenom nekonečný „povrch“ rozmanitých ukázek praxe.

Originálním přínosem Wittgensteinova myšlení je podle Geertze jeho schopnost přijmout „nejasnost hranic“ pojmů, z níž plyne, že mů-

51 Wittgenstein (1993a, § 66).

52 Geertz (1984, s. 272).

53 Wittgenstein (1993a, § 111).

54 Geertz (1993, s. 92). 
žeme přestat „neustále hledat rozdíly a obecnosti, které nám mají poskytnout vhled do jakési záhady“. ${ }^{55}$ Životní forma předpokládá takovou míru pozornosti vưči rozmanitým př́lkladům v rámci celku, která znemožňuje megalomanii etnocentrismu a provinční pohled relativismu. Ani relativismus, ani anti-relativismus nejsou z tohoto pohledu zcela udržitelné, protože pojmy a kategorie ztrácí své jasné hranice a je tedy obtížnější je porovnávat.

Z představy „hloubky“ nicméně vychází obě strany účastníků debaty o racionalitě. Jak relativisté, tak anti-relativisté vychází z představy kultury jako jasně vyznačených množin obsahujících určitý počet stejných členů, které všechny sdílí několik velkých podobností. Nejlépe tuto představu přibližuje podle Geertze Levi-Straussova metafora vlaků:

„Vlaky, které jedou vedle sebe, ve stejném směru a s podobnou rychlostí jako ten náš, jsou přinejmenším pro nás přiměřeně viditelné z našeho kupé. Ale vlaky z postranních nebo paralelních tratí, které jedou opačným směrem, vidět nejsou." 56

Metafora vlaků totiž nahlíží na kultury jako na sebe nezávislé, spolu nesouvisející, statické a jasně ohraničené celky. Stejně jako se míjí pasažéři různých vlaků, stejně tak nenajdou společnou řeč ani příslušníci různých kultur. Zatímco jedna kultura může být založena na racionalitě, druhá ji může zcela postrádat, a tím pádem postrádají jakýkoliv společný základ.

Ke kritice této myšlenky využívá Geertz Wittgensteinovu metaforu starého města. Jazyk je podle Wittgensteina tvořen klikatými starodávnými uličkami, ale i moderními rovnými ulicemi, oboje jsou jeho právoplatnými součástmi. ${ }^{57}$ Kultura je pro Geertze něco podobného. Vnitřní rozmanitost města, stejně jako jazyka a kultury, nejde shrnout pomocí zobecnění, pomocí rovných moderních ulic. Pokud bychom takové zobecnění přece jenom učinili, přišli bychom o pochopení toho, co je město. To je to, co se může stát, když se o kultuře uvažuje jako o vlaku.

Wittgensteinova metafora města nahrává Geertzovi i v případě další výčitky vưči představě kultury jako jasně ohraničeného homogenního

55 Geertz (2000a, s. xiii).

56 Tamtéž, s. 76.

57 Wittgenstein (1993a, § 18). 
celku. („Při kolika domech nebo ulicích začíná město být městem?““88) Antropologové se podle Geertze př́liš soustředí na staré město, aniž by věnovali dostatečnou pozornost novým čtvrtím na okraji, které se postupně rozrůstají, prolínají se se zbytkem města, vzájemně se ovlivňují. ${ }^{59}$ Nejenže představa kultur jako na sobě zcela nezávislých celků je podle antropologa teoreticky nemožná, $\mathrm{v}$ dnešním globalizovaném světě tato představa není udržitelná ani z praktického hlediska. Představitelé různých kultur žijí bok po boku vedle sebe, komunikují, ovlivňují se navzájem a vzájemně se utvářejí. Časy „lovců hlav, matrilinearistů nebo lidí, kteří předvídají počasí z vnitřností prasat“ skončily, ironicky podotýká Geertz. ${ }^{60}$ Pokud navážeme na metaforu vlaků, dnešní svět je víc podobný mezinárodnímu nádraží, kde se pasažéři z různých vlaků promíchávají v davu.

Přestože jak relativismus, tak anti-relativismus pracují s chybnou představou kultury, druhý zmíněný směr se podle Geertze vyznačuje i dalším prohřeškem. Brání nám zjistit, v jakém ohledu se vztahujeme ke světu, tím nám znemožňuje plnohodnotné budování vlastní identity. ${ }^{61}$ Různorodost jednotlivců, skupin lidí nebo kultur má napomáhat prohloubení jak vlastní subjektivity a jedinečnosti, tak příslušnosti ke společné kultuře. To je ovšem možné pouze za předpokladu neustálé konfrontace s jinakostí, a tedy uvědomění si vlastní odlišnosti. To nám současný svět, i navzdory přání etnocentristů, umožňuje.

Jako př́klad vnitřní nehomogennosti kultury a potřeby s ní pracovat uvádí Geertz „př́pad opilého indiána a stroje na dialýzu“ ${ }^{62}$ Krátce si ho popišme. Nedostatek strojů na dialýzu si vynutil vytvoření čekací listiny pacientů, jejichž pořadí, aby nedošlo k diskriminaci na základě movitosti, bylo vytvořeno na základě pořadí žádostí. Aby léčba byla účinná, bylo potřeba dodržovat celou řadu opatření včetně striktní diety. Když se dostala řada na indiána, ten odmítl omezit pití alkoholu. Doktoři, kteří mu dialýzu prováděli, se pohoršovali nad tím, že zabírá místo někomu, kdo si léčbu skutečně zaslouží, nicméně se neopovážili indiána od stroje odpojit. Takto př́běh pokračoval několik let, dokud indián nezemřel.

58 Tamtéž.

59 Geertz (1993, s. 73).

60 Geertz (2000a, s. 68).

61 Tamtéž, s. 75 .

62 Tamtéž, s. 81. 
Pomocí popsaného případu chce Geertz poukázat na vzájemné nepochopení dvou příslušníků stejné společnosti - indián jako tvrdošíjný fatalista nepovažoval vlastní změnu za do̊stojný krok, zatímco doktoři, kteří nevěřili na osud, ale na vlastní činy, jeho chování považovali za ostudné. Uvedený př́iklad popisuje střet myšlení a jednání několika představitelů stejné společnosti, který ovšem nejde povýšit na úroveň pravidla či vzorce. Šlo by dokonce tvrdit, že identita obou aktérů příběhu se dotváří právě díky vzájemnému střetu. Společnost tedy není jenom souborem rozmanitých, přitom však statických praktik nebo identit, ale i vysoce dynamickou entitou.

„Hranice jazyka jsou hranice mého světa,“ napsal Wittgenstein v Logicko-filozofickém traktátu. ${ }^{63}$ Podle Geertzova výkladu hranice jazyka nejsou hranicemi světa či životní formy proto, že jsme mentálně a jazykově uvězněni v naší společnosti a plně definováni jejími postoji, nýbrž proto, že skrz jazyk a myšlení definujeme vlastní „intelektuální, emoční a morální prostor, ve kterém žijeme“. ${ }^{64} \mathrm{~S}$ podobnou interpretací Wittgensteinovy pasáže přichází americká antropoložka Veena Das. Podle Das se identita subjektu utváří právě díky jeho hranicím. ${ }^{65}$ Pokud subjekt je hranicí svého světa, pak neexistuje „žádný určitý bod v časovém horizontu jeho života, který by se dal ztotožnit se zdrojem nebo podstatou jeho subjektivity“, tedy nemáme žádnou „esenciální“ podstatu, spíš naopak. ${ }^{66}$ Nejsme nikdy „ukončeným dílem“, protože jsme neustále konfrontováni s něčím novým. A zatímco práce etnografư byla dřív analytického rázu - pochopit vzdálenou kulturu a následně ji shrnout čtenáři -, dnes, když už jiné kultury nejsou vzdálené, ale jsou součástí naší (nebo globální) společnosti, hlavním předmětem zájmu badatelů by podle Geertze měly být zdánlivé „propasti mezi mnou a těmi, kdo myslí jinak než já“. ${ }^{67}$

Práce staré gardy antropologů byla podle Geertze v jakémsi smyslu jednodušší, protože působila za „starých dobrých časů pálení čarodějnic a kanibalismu“, dnešní svět nabízí méně zjevnou a sofistikovanější kulturní diverzitu, upozorňuje. ${ }^{68}$ Úkolem dnešních antropologů je podle

63 Wittgenstein (2007, § 5.6).

64 Geertz (2000a, s. 77).

65 Das (2007, s. 4).

66 Tamtéž.

67 Geertz (2000a, s. 83).

68 Tamtéž, s. 68. 
něj naučit se „rozlišovat jemnější rozdíly“, díky tomu by antropologické práce „mohly začít být sofistikovanější, když už budou méně okázalé“. ${ }^{99}$

Údělem novodobého antropologa není tedy zkoumání odlišností a podobností mezi jednotlivými společnostmi a kulturami, ale zkoumání sítě kulturních praktik a dynamiky jejich vzájemného ovlivňování a vývoje. Sociální, etnické, náboženské skupiny už nejsou vlaky, co se navzájem míjejí. Naopak, mají své průsečíky, společné prostory, přesahy, jedna skupina se prolíná s jinou. Zatímco dříve za jeden z argumentů pro vnímání kultur jako na sobě nezávislých entit sloužila geografická vzdálenost, dnešní globalizovaný svět tuto záminku pro tradiční představu kultury odstranil. Každodennost naší společnosti je tvořena rozmanitostí „západních lékařů a indiánských pacientů“, a právě na to by se novodobí etnografové měli podle Geertze soustředit. K pochopení dnešní společnosti nepomůže ani obecně formulovaný relativismus, ani etnocentrismus, ale pracné popisování rodinné podobností společenských praktik.

Wittgensteinovu životní formu Geertz chápe jako výzvu opustit tradiční společenskovědní výzkum založený na obecných rozdílech mezi „nimi“ a „,námi“. „Sociální svět se přirozeně nedělí na jasné „my“, do kterých se dokážeme vcítit, bez ohledu na to, jak moc se od nich lišíme, a záhadné „oni“, do kterých se vcítit nechceme, ačkoliv neúnavně bráníme jejich právo se od nás odlišovat,“ vzkazuje..$^{70}$ Tímto nám chce Geertz ř́ct, že hranice mezi jakýmikoliv „námi“ a „nimi“ je nejasná a pohyblivá. Jde o sociální konstrukt, který přizpůsobujeme vlastním potřebám, a na to by antropolog neměl zapomínat. Pojem „národ“ tak může zahrnovat zcela odlišné př́pady a praktiky než ten náš a naopak. Abychom pochopili vnitřní dynamiku kultury, neměli bychom se soustředit na celky, ale na různorodé praktiky, které se v něčem potkávají a v něčem se naopak rozcházejí.

\section{Závěr}

Pokud si z díla Geertze odneseme jen myšlenku chybnosti etnocentrismu a významu kulturního kontextu, nepřijde nám, dnešním antropologům a filozofưm, tato myšlenka nějak obzvlášt' objevná. Je ovšem nutné zdů-

69 Tamtéž.

70 Tamtéž, s. 76. 
raznit, že se Geertz prostřednictvím „zhuštěného popisu“ vymezuje vůči antropologii své doby, kdy popis každodenních praktik a uplatnění byl naprosto výjimečný. „Zatímco dnes je mnohem běžnější, že antropologové jsou obeznámeni s pracemi svých kolegů z humanitních oborů, je důležité si uvědomit, že v šedesátých a sedmdesátých letech patřil Geertz k hrstce vzdělanců obhajujících důležitost takového širšího intelektuálního přístupu,“ píše Hana Červinková ve své úvaze „Třicet let poté: Úvaha o interpretativním programu Clifforda Geertze““.71

Jak jsme si ovšem ukázali v této práci, Geertz se neomezil pouze na myšlenku kulturní podmíněnosti. Z Wittgensteinovy filozofie si odnesl mnohem víc - představu o kultuře jako činnosti a pojetí rodinné podobnosti uplatněné na výzkum kulturních praktik. Ve své práci se vzdal pokusu o nalezení objektivních vlastností kultury nebo její vnitřní logické struktury. Jak napsal už v Interpretaci kultur, „logika‘ je zrádné slovo, a o vzhledem $\mathrm{k}$ tomu, že odkazuje jak $\mathrm{k}$ formálním principům myšlení, tak k rozumovým spojením mezi fakty a událostmi““.72 Místo hledání formálních principů se soustředil na popis rozmanité každodenní praxe včetně té jazykové. $Z$ tohoto hlediska jde o odvážný krok dodnes, a to i přestože upřednostnění výzkumů praktik před standardním společenskovědním výzkumem může mít větší výpovědní hodnotu jak v předvídání kulturních změn, tak výzkumu postojů jednotlivých skupin.

Důležitým aspektem nové metodologie je také představa celku jako vzájemně příbuzných, ale nehomogenních členů. Potřeba vzít v úvahu jak „lékaře“, tak „indiánského pacienta“ se dnes ukazuje jako významná potřeba sociální politiky. Toto metodologické hledisko proto považuji za nepostradatelné jak v etnografickém výzkumu jednotlivých sociálních skupin, tak ve výzkumu uplatnění principů demokracie v kontextu dnešní společnosti.

\section{Literatura}

Červinková, H. (2000): „Třicet let poté: Úvaha o interpretativním programu Clifforda Geertze." In Interpretace Kultur: Vybrané Eseje, C. Geertz, Sociologické nakladatelství, Praha 2000, s. $503-527$.

71 Červinková (2000, s. 503).

72 Geertz (200ob, s. 446). 
Das, V. (2007): Life and Words: Violence and the Descent into the Ordinary. University of California Press, Berkeley.

Diamond, C. (1989): „Rules: Looking in the Right Place.“ In Wittgenstein: Attention to Particulars, eds. D. Z. Phillips \& P. Winch, Palgrave Macmillan, London, 1984, s. 12-34.

Evans-Pritchard, E. E. (1976): Witchcraft, Oracles, and Magic among the Azande. Clarendon Press, Oxford.

Geertz, C. (1984): „Distinguished Lecture: Anti Anti-Relativism.“ American Anthropologist 86 (2): 263-278.

Geertz, C. (1993): Local knowledge. Further essays in interpretive anthropology. Fontana Press, London.

Geertz, C. (2000a): Available light: Anthropological Reflections on Philosophical Topics. Princeton University Press, Princeton.

Geertz, C. (200ob): Interpretace Kultur: Vybrané Eseje. Sociologické nakladatelství, Praha.

Gellner, E. (1970): „Concepts and Society.“ In Rationality, ed. B. Wilson, Basil Blackwell, Oxford, 1970, s. 18-50.

Gellner, E. (2005): Words and Things. Routledge, London.

Hollis, M. \& Lukes, S. (1982): Rationality and Relativism. The MIT Press, Cambridge.

Jackson, M. (2014): „Ajàlá’s Heads: Reflections on Anthropology and Philosophy in a West African Setting." In The Ground Between: Anthropologists Engage Philosophy, eds. V. Das, M. Jackson, A. Kleinman \& B. Singh, Duke University Press, 2014, s. 27-50.

Wilson, B., ed. (1970): Rationality. Basil Blackwell, Oxford.

Winch, P. (1970): „Understanding a primitive society.“ In Rationality, ed. B. Wilson, Basil Blackwell, Oxford, 1970, s. 78-112.

Winch, P. (2004): Idea sociální vědy a její vztah k filosofii. Centrum pro studium demokracie a kultury, Brno.

Wittgenstein, L. (1993a): Fỉlozofická zkoumání. Filozofický ústav AV ČR, Praha. 
Wittgenstein, L. (1993b): Philosophical occasions 1912-1951. Eds. J. Klagge \& A. Nordmann, Hackett Publishing Co, Indianapolis.

Wittgenstein, L. (2007): Tractatus logico-philosophicus. OIKOYMENH, Praha.

Wittgenstein, L. (2010): Ojistotě. Academia, Praha.

\begin{abstract}
Application of the philosophy of late L. Wittgenstein in C. Geertz's work

The goal of the article is to analyze how Clifford Geertz applies L. Wittgenstein's late philosophy in the methodology of the social sciences. In his works, Geertz disagrees with the criticss of relativism in anthropology, although refuses to take the position of relativist or anti-relativist. He calls his position an anti anti-relativist. According to him, the main problem of both sides is the misconception of culture as a non-dynamic and closed whole, which results from the philosophical idea of "ideal" concepts. According to him, such an idea is particularly unsustainable in today's globalized interconnected world. On the contrary, he considers Wittgenstein's concept of "language game" to be a suitable methodological tool, which offers a view of language and culture as a network of similar practices, family resemblence that cannot be summarized in a number of premises and doesn't have clear boundaries.
\end{abstract}

Key words: anti anti-relativism, anthropology, language game, Wittgenstein, Geertz

Vejnbender, K. (2020): „Uplatnění pozdní filozofie L. Wittgensteina v myšlení C. Geertze." Filosofie dnes 12 (2): 20-40. Dostupné z www.filosofiednes.ff.uhk.cz 